\title{
A Review on Beneficial Effects of PGPR and Noble Liquid Manures in Enhancing Soil Fertility and Sustainability
}

\author{
Perminder Singh Brar*, Rajesh Kaushal and Gitika Bhardwaj \\ Department of Soil Science and Water management, Dr. YS Parmar University of \\ Horticulture and Forestry Nauni, Solan, Himachal Pradesh, India \\ *Corresponding author
}

\section{A B S T R A C T}

\section{Keywords}

Soil fertility and sustainability, PGPR,

Panchagavya

Article Info

Accepted:

04 March 2019

Available Online:

10 April 2019
Organic inputs being bulky and concentrated in nature are capable of supplying plant nutrients and enhance soil physical environment. These manures containing organically bound macro and other micro-nutrients which influence plant growth and development, which further also play role in maintaining soil sustainability. The use of PGPR is steadily increased in agriculture and offers an attractive way to supplement and/or replace chemical inputs. PGPR are known to increase germination percentage seedling vigour, emergence, plant stand, root and shoot growth, total biomass of the plant, seed weight, early flowering, grains, fodder and fruit yields etc. Also, Panchagavya is a low cost preparation to support plant growth in organic agriculture. Panchagavya contains growth regulatory substances such as IAA (Indole Acetic Acid), GA, Cytokinins, essential plant nutrients, and effective microorganisms like lactic acid bacterium, yeast and actinomycetes. Further, Jeevamrut contains enormous amount of microbial load which multiply and act as soil tonic. Its application enhances microbial activity in the soil and ultimately ensuring the availability and uptake of nutrients by the crops. Even, Amritpani and bio-fertilizer along with chemical fertilizer also affects soil microbial biomass as well as nutrient uptake.

\section{Introduction}

Organic manures are natural products derived from organic sources like animal waste, vegetable compost, agricultural residues, human excreta etc. These are actually natural products that decay and get mixed with soil thereby providing plant nutrients and increasing fertility of soil. The bulky organic manures contain nutrients in very small amount and are applied in large quantities. Concentrated organic manures have higher nutrient content than bulky organic manure.
The long term indiscriminate use of chemicals during last few decades and the least attention to ecological agricultural principles resulted in soil degradation (physico-chemical and biological properties), ground water pollution and environmental pollution leading to ecological imbalance which has affected the harmony existed among soil, plant, bio-life, animals and human. Organic manure increases the yield and long term usage will give maximum output. Worldwide, there is growing interest in the use of these manures due to depletion in the soil organic carbon 
status. Sustainable practices providing organic amendments are useful tool to maintain organic matter content in agricultural soils, preserving and improving soil fertility. The Integrated Nutrient Management (INM) is an approach to nutrient management in which organic sources, inorganic sources and fertilizers are used in a judicious and synchronous way to maintain soil fertility and productivity. Liquid manure such as Panchagavya, Jeevamrut and Amritpani are valuable sources of nutrients for crop production. Use of Liquid manures results in increase in soil microbial activity and microbial biomass. The application of liquid organic inputs like Panchagavya, Jeevamrut and Amritpani etc results in increase in number of beneficial microbes and also shows profound effect on soil enzymes activity. Thus they enhance the growth of crop and can help in sustaining of safe environment and crop productivity. Bio-fertilizers are living microorganisms with origin of bacteria, fungi and algae. These sources of nutrients along with bio-fertilizers/PGPR are becoming popular among farmers who are converting themselves from chemical farming to Organic Farming (OF). Therefore this review focuses on the potential value of PGPR and liquid organic inputs and a brief overview of the effects of these manures on soil properties and crop productivity.

\section{Effect of Plant Growth Promoting Rhizobacteria (PGPR) on the growth and yield}

Plant Growth Promoting Rhizobacteria (PGPR) are group of heterogeneous bacteria known to rapidly colonize the rhizosphere and can stimulate the plant growth and development through direct (nutrient mobilization, phytohormone production like auxins, cytokinins, gibberellins, enhancing plant nutrition by solubilization and siderophores production, lowering of ethylene levels and induction of systemic resistance) and through indirect ways such as plant protection including deleterious microorganisms or root pathogens that inhibit plant growth, including anti-biotic production, parasitism, competition for nutrition and niches within the rhizosphere, synthesis of extracellular enzyme to hydrolyze the fungal cell wall, decreasing pollutant toxicity (Bhattacharyya and Jha, 2012; Podile and Kishore, 2006).

PGPR are known to increase germination percentage seedling vigour, emergence, plant stand, root and shoot growth, total biomass of the plant, seed weight, early flowering, grains, fodder and fruit yields etc. The interaction between plant and microbes mainly plant growth promoting rhizobacteria (PGPR) are largely facilitated by the rhizospheric soil (Kloepper et al., 1980). The concept of PGPR began to gain importance and a large number of bacterial strains have been isolated, screened (Chanway and Holl, 1993; Cattelan et al., 1999) and evaluated for plant growth promotion. Datta et al., (2011) studied the effect of PGPR on the growth and yield of chilli under field conditions and recorded remarkable increase in growth characteristics such as total number of fruits, fruit weight and yield in plants with combined inoculation under field conditions.

Das and Singh (2014) also documented that manure application with PGPR showed higher organic carbon in soil as compared to the sole application of manures. The combined application of manures with PGPR also increased the $\mathrm{N}, \mathrm{P}, \mathrm{K}$ content in soils in comparison to the application of manures without PGPR. Similar results were also recorded by Singh and Subbarao (1979), Prasad and Chandra (2003); Gunasekaran et al., (2004) while working with PSB and reported that available $\mathrm{P}$ content increased by the application of PSB. Kucey et al., (1989) 
reported that phosphorus solubilizers increase the availability of phosphates in the soil and could enhance the plant growth of legumes by increasing the efficiency of biological nitrogen fixation. Shinde et al., (2008) also reported that application of PGPR increases the available nitrogen, phosphate and potash. Akhtar et al., (2009) concluded that the application of PGPR and compost in combination with chemical fertilizers significantly improved the growth and yield of wheat. Further the higher $\mathrm{N}$ content was recorded with the application of seed inoculation with PGPR along with recommended chemical fertilizer. Similar findings were also recorded by Mehdi et al., (2011) and Marcos et al., (1995); Das et al., (2004); Zahir et al., (2007).

Effect of liquid organic inputs (Panchagavya, Jeevamrut and Amritpani) on the growth and yield

Panchagavya is a low cost preparation to support plant growth in organic agriculture. Panchagavya enhance the biological efficiency of the crop plant, quality and yield of fruits and vegetables (Nataranjan, 2002). This liquid manure is prepared by mixing cow dung, cow urine, cow milk, cow ghee, cow curd, jiggery, sugarcane juice, coconut, and banana. Panchagavya contains growth regulatory substances such as IAA (Indole Acetic Acid), GA, Cytokinins, essential plant nutrients, and effective microorganisms like lactic acid bacterium, yeast and actinomycetes.

It also contains beneficial microbes like Acetobacter, Azospirillum and Phosphobacterium and plant protection substances (Somasundaram et al., 2003; Swaminathan, 2007 and Devakumar et al., 2008) also reported the presence of naturally occurring beneficial microorganism predominantly lactic acid bacteria, yeast, actinomycetes, photosynthetic bacteria, nitrogen fixers, phosphorus solubilizer and fungi in Panchagavya.

Gore and Sreenivasa (2011) noted that the panchagavya is an efficient plant growth stimulant, it enhances the biological efficiency of crops. It is used to activate biological reactions in the soil and to protect plant from diseases incidence. They also concluded that significant increase in plant height and root length was recorded with the application of recommended dose of fertilizer + beejamrut + panchagavya + jeevamrut. Sakubai et al., (2014) studied effect of bioinoculantmycorrhiza and organic formulations that is panchagavya and amritpani on growth, yield and quality of buckwheat and recommended that the organic treatment (VAM + panchagavya + amritpani @3\% drench and spray) for enhanced growth and yield parameters of Buckwheat. Significant effect of panchagavya on root length, shoot length of Cajanus cajan were also recommended by Amalraj et al., (2013). Selvi et al (2002) advocated that application of panchagavya significantly influenced the height, length of flowering, shoot and floral character and early flowering in brinjal. Further foliar application @ 5\% have significant effect on chlorophyll content, total phenolic content $(15.7 \%)$, total carotenoids (24.8\%), DPPH activity (51\%) and Ascorbic acid (1.1\%). Jain et al., (2014) tried different concentration of panchagavya and reported that $4 \%$ foliar application increase plant height and chlorophyll content besides having significant effect on available macro $(\mathrm{N}, \mathrm{P}, \mathrm{K})$, micro nutrients $(\mathrm{Zn}, \mathrm{Cu}, \mathrm{Mn})$ and microbial activity as compared to FYM and vermicompost. Vimalendran and Wahab (2013) also recommended that four sprays of panchagavya $(15,25,35$ days after sowing) @ 3\% concentration produce high yield of baby corn. Mohan (2008) evaluated different organic growth promoters' viz. panchagavya 
and amritpani on yield and quality parameters of brinjal and tomato and concluded that panchagavya is most cost effective in increasing yield and quality of fruits of both the crops. Fruit yield of tomato differed significantly with the application of different liquid organic manures. The application of recommended dose of fertilizers + panchagavya resulted in significantly higher fruit yield due to enhanced nutrient availability and uptake by plant. The combined application also improves soil physico-chemical and biological properties further the application of panchagavya alone had better effect as compared to RDF which could be attributed to higher amount of nutrients microbial activity and plant growth promoters present in it (Gore and Sreenivasa, 2011). Birendra and Christopher (2007) also noted that foliar spray of panchagavya at the rate of $3 \%$ resulted in significant increase in the yield attributes. Kalarani (1991) reported that the action of growth regulators in the plant system stimulated the necessary growth and development in plants and better yield. Sanjutha et al., (2008) found that the physiological attributes like leaf area index (LAI), chlorophyll content and total dry matter production are closely related with yield parameters. The plots that have received $(\mathrm{FYM}+\mathrm{RDF})+$ panchagavya foliar application recorded the highest values. They have ascribed the increase in the parameters to better availability of nutrients from organic and foliar source of nutrients as well as affective conversion of nutrients such as Fe, $\mathrm{Mg}$ and $\mathrm{Zn}$.

Amritpani is prepared by mixing the ratio of cow dung, cow urine and honey in water. A very scanty report is available in literature on the efficacy of organic growth promoters and their effect on growth and yield of vegetable crops and field crops (Ram and Pathak, 2007). The field experiment was conducted by Ghodpage et al., (2009) under rain fed conditions to study the effect of amritpani and bio-fertilizer along with chemical fertilizer on microbial population, nutrient uptake. More et al (2008) also reported that application of $5 \mathrm{t}$ $\mathrm{ha}^{-1} \mathrm{FYM}+$ amritpani + PSB + rhizobium recorded significantly higher value for growth attributes, yield attributes and yield of soybeancompare to other tried combination such as application of $5 \mathrm{t} \mathrm{ha}^{-1}$ FYM, $5 \mathrm{t} \mathrm{ha}^{-1}$ FYM + amritpani, $5 \mathrm{t} \mathrm{ha}^{-1} \mathrm{FYM}+\mathrm{PSB}$.

Jeevamrut is a fermented liquid product prepared by mixing up cow dung with cow urine, jaggery, legume flour and handful of live soil (Palekar, 2006). It contains enormous amount of microbial load which multiply and act as soil tonic. Its application enhances microbial activity in the soil and ultimately ensuring the availability and uptake of nutrients by the crops. Jeevamrut promotes immense biological activity in soil and enhance nutrient availability to crop (Gore and Sreenivasa, 2011). Jeevamrut is a low cost improvised preparation that enriches the soil with indigenous microorganisms, therefore required for mineralization (Gore and Sreenivasa, 2011). Patil et al., (2014) investigated the effect of organic input on growth and quality of pigeon pea and reported that growth attributes viz. plant height, number of branches per plant, number of compound leaves and leaf area per plant, seed and stock yield significantly got increased by application of FYM @ $20.5 \mathrm{t} \mathrm{ha}^{-1}+$ jeevamrut @ $5001 \mathrm{ha}^{-1}$ (30 and 45 days after sowing). Boraiah (2013) conducted studies on effect of organic liquid formulations and manures on growth and yield of capsicum and concluded that jeevamrut recorded maximum fruit yield compared to other tried combinations.

Manjunatha et al., (2009) studied the effect of Farm Yard Manure treated with jeevamrut on soil properties and yield of sunflower. They also found that the application of jeevamrut increased the activity of microbes by 
solubilization and uptake nutrient was enhanced. Chandrakala (2008) reported that the combined application of FYM and beejamrut + jeevamrut + panchagavya had significant effect on dehydrogenase activity of soil. Dwivedi et al., (2014) studied the effect of organic amendments like amritpani, jeevamrut + vermicompost and FYM on vegetative parameters, flowering and fruiting in Cape gooseberry. A significant increase in plant height $(70.25 \mathrm{~cm})$ was recorded with the application of jeevamrut @ 5\% besides positive impacts on physico-chemical properties of soil.

\section{Acknowledgements}

The authors are thankful to the Department of Soil Science and Water Management, Dr. YS Parmar University of Horticulture and Forestry, Nauni, Solan (Himachal Pradesh) for providing necessary research facilities.

\section{References}

Akhtar, M.J., Asghar, H.N, Shahzad, K and Arshad M. 2009. Role of plant growth promoting rhizobacteria applied in combination with compost and mineral fertilizers to improve growth and yield of wheat (Triticum aestivum L.). Pakistan Journal of Botany 41: 381-390.

Amalraj, D.L., Kumar, G.P, Ahmed, S.K.M and Kishore, N. 2013.Microbiological analysis of Panchagavya, vermicompost, and FYM and their effect on plant growth promotion of pigeon pea (Cajanus cajan L.) in India. Organic Agriculture 3(1): 2329.

Bhattacharyya, P.N., and Jha, D.K. 2012.Plant growth-promoting rhizobacteria (PGPR): emergence in agriculture. World Journal of Microbiology and Biotechnology 28: 1327-1350.
Birendra, K.Y., and Christopher, L.A. 2007. Use of panchagavya as a growth stimulant and biopesticide in agriculture. In: Agriculture and Environment. A Kumar (ed.). APH Publishing Corporation, New Delhi., pp. $65-70$.

Boraiah, B. 2013. Effect of organic liquid formulations and manures on growth and yield of capsicum (Capsicum annuum L. var. grossum). Ph.D Thesis, University of Agricultural Sciences, Bangalore.

Cattelan, A.J., Hartel, P.G and Fuhrmann, J.J. 1999. Screening for plant growth promoting rhizobacteria to promote early soybean growth. Soil Science Society of America Journal 63:16701680.

Chandrakala, M. 2008. Effect of FYM and fermented liquid manures on yield and quality of chili. M. Sc (Agri) Thesis, University of Agricultural Sciences, Dharwad.

Chanway, C.P., and Holl, F.B. 1993. First year field performance of spruce seedlings inoculated with plant growth promoting rhizobacteria. Canadian Journal of Microbiology 39:10841088.

Das, A., Parsad, M and Gautam, R.C. 2004. Residual effect of organic and inorganic sources of nitrogen applied to cotton (Gossipium hirsutum) on succeeding wheat (Triticum aestivum). Indian Journal of Agronomy 49(3): 143-146.

Das, I., and Singh, A.P. 2014.Effect of pgpr and organic manures on soil properties of organically cultivated mungbean. The Bioscan 9(1): 27-29

Datta, M., Palit, R, Sengupta, C, Pandit, M.K and Banerjee, S. 2011. Plant growth promoting rhizobacteria enhance growth and yield of chilli (Capsicum annuит) under field conditions. 
Australian Journal of Crop Science 5: 531-536.

Devakumar, N.G., Rao, G.E, Gowda, S.B. 2008. Activities of organic farming research centre, Navile, Shivamogga, University of Agricultural Sciences, Bangalore. 12p.

Dwivedi, D.H., Yadav, A.K, Kumar, P and Gautam, S.K. 2014. Integrated nutrient management in cape gooseberry (Physalis peruviana) for peri urban horticulture. Indian Journal of Applied Research 4(12): 2249$555 \mathrm{X}$.

Ghodpage, R.M., Balpande, S.S, Herale, M.A and Modhumita, G. 2009.Effect of amrutpani and bio-fertilizer with fertilizer and vermicompost in soil microbiotic and yield of rainfed cotton. Journal of Soil and Crops 19(2): 343-346.

Gore, N.S., and Sreenivasa, M.N. 2011. Influence of liquid organic manures on growth, nutrient content and yield of tomato (Lycopersicon esculentum Mill.) in the sterilized soil. Karnataka Journal of Agricultural Sciences 24(2): 153-157.

Gunasekaran, S., Balachandar, D, Mohanasundaram, K. 2004. Studies on synergism between Rhizobium, plant growth promoting rhizobacteria (PGPR) and phosphate solubilizing bacteria in blackgram. In: Biofertilizer technology for rice based cropping system. S Kannaiyan, K Kumar, K Govimdarajan (eds.). Scientific Publishers, Jodhpur. pp. 269-273.

Kalarani, M.K. 1991. Senescence regulation in soybean (Glycine max L.). M.Sc. (Agri.) Thesis, Tamil Nadu Agricultural University, Coimbatore (India).

Kloepper, J.W, Leong, J, Teintze, $\mathrm{M}$ and Schroth, M.N. 1980. Enhancing plant growth by siderophores produced by plant growth-promoting rhizobacteria. Nature 286: 885-886.

Kucey, R.M.N., Janzen, H.H and Leggett, M.E. 1989. Microbially mediated increases in plant-available phosphorus. Advances in Agronomy 42: 199-228.

Manjunatha, G.S., Upperi, S.N, Pujari, B.T, Yeledahulli, N.A and Kuligod, V.B. 2009. Effect of farm yard manure treated with Jeevamrutha on yield attributes, yield and economics of sunflower. Karnataka Journal of Agricultural Sciences 22(1): 198-199.

Marcos, A.K., and Suttle, J.C. 1995. Effect of compost on rhizosphere microflora of tomato and on the incidence of plant growth promoting rhizobacteria. Canadian Journal of Microbiology 61(1): 194-199.

Mehdi, S.M., Sarfaraz, S.M, Abbas, S.T, Shabbir, G and Akhtar, J. 2011. Integrated nutrient management on rice and wheat cropping system in a recently claimed soils. Journal of Soil Science and Environment Management 30(1): 36-43.

Mohan, B. 2008. Evaluation of organic growth promoters on yield of dryland vegetable crops in India. Journal of Organic Systems 3(1): 24.

More, S.R., Mendhe, S.N, Kolte, H.S, Venprediwar, M.D and Choudhary, R.L. 2008. Growth and yield attributes of soybean as influenced by nutrient management. Journal of Soil and Crops 18(1): 154-157.

Natarajan, K. 2002. Panchagavya- A manual.Moth Ind. Press, Mapusa, Goa, India. 33p.

Palekar, S. 2006. Text book on Shoonya Bandovaladanaisargika Krushi, published by Swamy Anand, Agri Prakashana, Bangalore.

Patil, D.B., Murade, N.B, Dhavan S.P, Jagtap, H.D and Chopade, M.B. 2014. Effect 
of organic inputs on growth and quality of pigeonpea (Cajanus cajan). Bioinfolet 11: 421-424.

Podile, A.R., and Kishore, G.K. 2006. Plant growth-promoting rhizobacteria. In: Plant-Associated Bacteria. S.S, Gnanamanickam (ed.). Springer, Netherland. pp. 195-230.

Prasad, H., and Chandra, R. 2003. Growth pattern of urdbean Rhizobium sp. with PSB and PGPR in consortia. Journal of the Indian Society of Soil Science 51: 76-78.

Ram, R.A., and Pathak, R.K. 2007. Integration of organic farming practices for sustainable production of guava: A case study. International Guava Symposium 2007, Lucknow, India.

Sakhubai, H.T., Laxminarayana, $\mathrm{H}$ and Chaya, P. 2014. Effect of bioinoculants and bioformulations on growth, yield and quality of buckwheat. International Journal of Agricultural Sciences and Veterinary Medicine 2(4): 2320-3730.

Sanjutha, S., Subramanian, S, Rani, I and Maheswari, J. 2008.Integrated nutrient Management in Kalmegh. Research Journal of Agriculture and Biological Sciences 4(2): 141-145.

Shinde, D.B., Vahini, C and Jadhav, A.C.
2008. Influence of plant growth promoting rhizobacteria (PGPRs) on nutrient availability and rhizobacterial population in groundnut cropped soil. Journal of Maharashtra Agricultural Universities 33(3): 335-338.

Singh, C.S., and SubbaRao, N.S. 1979. Associative effect of Azospirillum brasilense with Rhizobium japonicum on nodulation of soybean (Glycine max). Plant and Soil 53(3): 387-392.

Somasundaram, E., Sankaranan, N, Meena, S, Thiyagarajan, T. M, Chandaragiri, K, Pannerselvam, S. 2003. Response of green gram to varied levels of Panchagavya (organic nutrition) foliar spray. Madras Agricultural Journal 90: 169-172.

Swaminathan, C, Swaminatha, V and Vijaylakshmi, K. 2007. Panchagavya: boon to organic Farming, International Book Distributing Co., Lucknow.

Zahir, Z.A., Naveed, M, Zafar, M.I, Rehman, H.S, Arshad, M and Khalid, M. 2007. Evaluation of composted organic waste enriched with nitrogen and LTryptophan for improving growth and yield of wheat (Triticum aestivum $\mathrm{L}$.). Pakistan Journal of Botany 39(5): 1739-1749.

\section{How to cite this article:}

Perminder Singh Brar, Rajesh Kaushal and Gitika Bhardwaj. 2019. A Review on Beneficial Effects of PGPR and Noble Liquid Manures in Enhancing Soil Fertility and Sustainability. Int.J.Curr.Microbiol.App.Sci. 8(04): 409-415. doi: https://doi.org/10.20546/ijcmas.2019.804.045 